\title{
Sponsorship investments: do they deliver brand awareness for all sponsors?
}

\author{
Catherine MPOLOKENG SEPHAPO \\ University of South Africa, Pretoria, South Africa \\ sephacm@unisa.ac.za
}

\begin{abstract}
Sponsorship as a marketing communications tool is well adopted in South Africa across various areas such as sports and entertainment. Although world markets have experienced economic turmoil in the last few years, the sponsorship market may be considered to be thriving as companies use this marketing communication tool as a vehicle to create and maintain relationships. The purpose of this study was to explore which sponsors of the South African National Rugby team are sports consumers aware of as a result of the sponsorship. Literature states that awareness also influences the judgments about brands in the consideration set, even without any brand associations in the consumer's mind. In low involvement decision; where consumers do not need to search extensively for information in order to make a decision; minimal brand awareness levels may be enough to convince the consumer to make their final choice. The study is exploratory in nature however provides a South African perspective on how effective the sponsorship of the Springbok is with regards to creating awareness of the sponsors among sports consumers. The study made use of a qualitative approach whereby primary data was collected by means of focus groups and naïve sketches. Data collected was analyzed by means of content analysis. The findings suggest that participants were predominantly aware of the key sponsors of the Springboks; these were sponsors who had their branding on the Springbok jersey worn during rugby matches. The factors that participants mentioned to contribute to their awareness of the sponsors were the branding on the Springbok playing jersey as well as television adverts along with other promotional tools. This study urges sponsors to not only rely on the sponsorship initiative to create awareness but rather leverage the sponsorship with tools that are relevant to their target audience. This study contributes to sponsorship literature relating to the effectiveness of sponsorship; particularly from a South African perspective.
\end{abstract}

Keywords: sponsorship, brand awareness, consumers, sports, marketing communication.

Please cite the article as follows: Mpolokeng Sephapo, C. (2017), "Sponsorship investments: do they deliver brand awareness for all sponsors?", Management \& Marketing. Challenges for the Knowledge Society, Vol. 12, No. 1, pp. 103-123. DOI: 10.1515/mmcks-2017-0007

\section{Introduction}

In an environment where consumers are bombarded with marketing messages, organizations are challenged with the task of effectively reaching their target markets. Marketing communication tools, such as sponsorship, are leveraged to yield a return on investment. Alay (2008) describes sponsorship as the provision of resources; which can be in cash, human resources or equipment by an organization (known as the sponsor) directly to an individual or body (the sponsored organization) in order to empower the latter to follow some activity in return for benefits stipulated in terms of the sponsor's promotional strategy which can be expressed in terms of corporate objectives, marketing objectives or media objectives. Sponsorship was previously adopted as a corporate social responsibility initiative (CSI), although this may still be the case, companies have come to realize that this marketing communication tool can be used to achieve both organizational and marketing objectives. 
Sponsorship in South Africa is well adopted by many organizations stretching across various fields. For the purpose of this study, the discussion will centre on sponsorship within the context of the South African rugby industry. Rugby in South Africa is comfortably the most profitable sport as it receives the lion's share of sponsorship budgets (Mufumba Consulting, 2009; Koenderman, 2011). In 2011, the South African Rugby Union (SARU) lost their main sponsor (Sasol) but received financial provision from South Africa's largest financial service provider, Absa. This sponsorship was estimated to be worth R50 million a year (Mufumba Consulting, 2009). Although the Absa sponsorship of the Springboks came to an end in December 2015, this agreement demonstrates that sponsorship can be very expensive and when used correctly be a valuable asset for sponsors and sponsored organizations. SARU's sponsorship income has increased enormously in previous years. In 2003 for example, sponsorship accounted for only 28\% of SARU's income and increased to 41\% in 2011 (Gerber-Nel, 2004; Levet, 2012). The Springbok brand, which is the focus of this study, has contributed to this increase through the attraction of new investors and old investors expanding their portfolio. According to Sport24 (2014), SARU group revenue increased in 2013 to R795 million by 14\% from the 2012 level of R700 million. This increase in revenue was mainly due to increases in broadcasting rights as well as sponsorship revenues (Sport24, 2014). In 2016, the South African Breweries (SAB) announced the renewal of their sponsorship of the SA rugby brand (SARU, 2016). This meant that the world-renowned Castle Lager brand would extend its association with the SA rugby to 23 years (SARU, 2016). Although the monetary value of this sponsorship was not disclosed, one can deduce that the extended loyalty to the SA rugby brand has proved to be beneficial for SAB over the years.

With companies investing large portions of their marketing budgets in sponsorship agreements, the question that remains to be answered is whether this investment is fruitful in terms of influencing consumers or creating substantial brand awareness among. Sponsorship as a marketing communication tool is not a standalone tool but one that can beneficial to sponsors when leveraged with other marketing communication tools to reap the ultimate return on investment. This implies that more money needs to be invested to essentially make the sponsorship 'work'. Taking into consideration that not all companies have extensive marketing budgets whereby they can afford to invest R50 million annually into a sponsorship deal, can it be said that sponsorship is equally beneficial for them? This implication can be easily overlooked because of the idea sponsors may have of being associated with established brands. Not every sponsor will have their branding on Springbok attire therefore other promotional tools would be needed to emphasize the association in the minds of the consumers.

The remainder of the paper addresses the overview of the South African Rugby Union, the Springboks, consumer behavior within the sports environment and the conceptual framework for awareness. The methodology employed in the study is discussed and the paper concludes with the recommendations and conclusion for the consideration of sponsors. 


\section{Literature review}

In the following section, a discussion will be provided on the overview of sponsorship within the South African rugby industry, the types of sports consumers are discussed as well as the conceptual framework for awareness.

\section{An overview of the South African Rugby Union}

SARU, which is the national governing body for rugby, was founded in 1992 as a result of the merger of what was known as the South African Rugby Board and the South African Rugby Union (Sport Know How, 2011). This entity has undergone significant changes in recent years, having been divided into two divisions, namely the non-commercial and the commercial side (Gerber-Nel, 2004). The non-commercial arm of SARU was formed to develop rugby in the country, link with the International Rugby Board and manage amateur teams (Gerber-Nel, 2004). SA Rugby (Pty) Ltd was established to manage all SARU's commercial activities locally and internationally (SARU, 2011). SA Rugby (Pty) Ltd is liable for revenue maintenance and growth from all commercial properties including rights, the Springbok team, brands, sponsorship, merchandising and competitions (SARU, 2011). There are a number of national teams that are managed by SARU and fall under the SARU umbrella. Since the focus of this study is on the sponsors of the Springboks, a brief overview of the Springboks is provided next.

\section{The Springboks}

South Africa participated in their very first international rugby competition in 1891, but it was not until they toured Britain in 1906 that they became known as the Springboks with the springbok as the official symbol (Telegraph Media, 2008). In 1977, the Gleneagles Agreement was signed by the members of the Commonwealth which discouraged any sporting contact with South Africa as a result of the apartheid policy (Rugby Football History, 2007). However, from 1990 to 1991, the legal apparatus of apartheid were abolished and the Springboks were allowed to compete in international rugby competitions (Springbok Supporter, 2011). The Springboks are a team that brings about national pride and participate in various international competitions such as the Rugby World Cup as well as the Rugby Championship. The Springboks brand has in the past developed into a worldrenowned brand that organizations may want to sponsor. Table 1 illustrates the types of sponsors as identified in literature that are applicable to the Springbok brand.

Table 1. Types of sponsors

\begin{tabular}{|l|l|l|}
\hline Type of sponsor & Description & Example \\
\hline $\begin{array}{l}\text { Primary or } \\
\text { naming rights } \\
\text { sponsor }\end{array}$ & $\begin{array}{l}\text { A primary or naming rights sponsor can } \\
\text { also be called a title sponsor. Title } \\
\text { sponsors pay a premium fee to have } \\
\text { their name as part of the sporting event } \\
\text { itself (ASA, 2015). }\end{array}$ & $\begin{array}{l}\text { An example of atle sponsor of the } \\
\text { Springboks from July 2011 till December } \\
\text { 2015 was Absa }\end{array}$ \\
\hline $\begin{array}{l}\text { Secondary } \\
\text { sponsor }\end{array}$ & $\begin{array}{l}\text { Secondary sponsors are very similar to } \\
\text { primary sponsors. The distinction } \\
\text { between these sponsors lies with the } \\
\text { specific rights of the sponsor. }\end{array}$ & $\begin{array}{l}\text { BMW was a sponsor of the Springboks till } \\
\text { December 2015. Although they were not } \\
\text { title sponsors, they could have been } \\
\text { considered to be secondary sponsors of } \\
\text { the Springboks }\end{array}$ \\
\hline
\end{tabular}




\begin{tabular}{|l|l|l|}
\hline Type of sponsor & Description & Example \\
\hline $\begin{array}{l}\text { Technical } \\
\text { sponsors }\end{array}$ & $\begin{array}{l}\text { Technical sponsors tend to supply } \\
\text { official equipment to be used in the } \\
\text { sporting event (Tassiopoulos, 2010, p. } \\
\text { 281). }\end{array}$ & $\begin{array}{l}\text { An example of a technical sponsor of the } \\
\text { Springboks can be regarded as Gilbert; as } \\
\text { they supply rugby balls for Springbok } \\
\text { games }\end{array}$ \\
\hline Official sponsors & $\begin{array}{l}\text { This type of sponsorship is similar to the } \\
\text { technical sponsor, but the official } \\
\text { supplier does not supply equipment or } \\
\text { other products linked directly with the } \\
\text { sporting event (Tassiopoulos, 2010, p. } \\
\text { 282). }\end{array}$ & $\begin{array}{l}\text { Virgin Active is a good example of an } \\
\text { official sponsor of the Springboks as the } \\
\text { company does not supply equipment or } \\
\text { other products that are related to rugby } \\
\text { matches. }\end{array}$ \\
\hline $\begin{array}{l}\text { Broadcast } \\
\text { sponsors }\end{array}$ & $\begin{array}{l}\text { Broadcast sponsors are defined as those } \\
\text { sponsors who have the rights to } \\
\text { broadcast the sporting event } \\
\text { (Tassiopoulos, 2010, p. 282). }\end{array}$ & $\begin{array}{l}\text { In South Africa, the SABC and SuperSport } \\
\text { are role players in sport broadcasting } \\
\text { (Mail \& Guardian, 2012). }\end{array}$ \\
\hline \multicolumn{2}{|c|}{ Source: Adapted from: ASA (2015); Mail \& Guardian (2012); Tassiopoulos (2010) }
\end{tabular}

The next discussion will highlight the reasons why sponsorship is well adopted in the South African ruby industry and why sponsors may feel that this marketing communication tool is effective to achieve both organizational and marketing objectives.

Reasons for the growth in the adoption sponsorship within the South African rugby industry The discussion thus far has illustrated that companies in South Africa spend large portions of their marketing budgets on sponsorship deals, particularly on sponsoring the Springboks. The following are considered reasons for the growth in the adoption of sponsorship within the South African rugby industry:

\section{Concerns about traditional promotional methods}

Companies are concerned about the significance that traditional forms of marketing will have on their organization. Advancements in the use of technology have created various marketing opportunities for organizations to communicate with their target audience. On the other hand the new communication channels have also created the problem for consumers of being bombarded with advertising messages across their various personal devices (Amoako, Dartey-Baah, Dzogbenuku \& Kwesie, 2012). Advertising clutter can be regarded as the situation whereby consumers are overstimulated or ever exposed to advertising messaged (Shimp, 2010). Traditional promotional tools such as television and radio have also become more expensive to use. Sponsorship can be seen as an alternative promotional tool that avoids clutter and permits distinctive messages to be seen or heard (Amoako et al., 2012). According to Meenaghan (2001), sponsorship is seen as a more subtle and indirect tool involving a camouflaged intent to influence resulting in a lowering of consumer defense mechanisms (Meenaghan, 2001). Traditional promotional tools are seen to be more forceful leading to advertising clutter. This clutter heightens the consumer's defense mechanisms thus leading to consumers avoiding such messages.

\section{Creation of favorable association}

The second reason why sponsorship has grown in the South African rugby industry is that it creates favorable association between the sponsor and the sponsored organizations. 
Research studies have found that the main objective of sponsors is to increase brand awareness and improve their brand (Cornwell, Roy \& Steinard, 2001; Marshall \& Cook, 1991; Shanklin \& Kuzma, 1992). Sponsorship is increasingly being seen as a tool in which awareness can be created while at the same time generating an association between the values of the sponsored organization and the sponsoring company (Amoako et al., 2012). Consumers tend to transfer the image of the sponsored organization to the sponsor therefore the association can be beneficial for all the parties involved in the sponsorship agreement.

\section{Overcome language or cultural barriers}

Rugby in South Africa can be regarded as one of the most followed sports in the sense that it has a large audience from different cultural backgrounds. According to research conducted by Repucom (2012), 20.6\% of the population showed great interest in rugby; $68 \%$ of these individuals were male and $32 \%$ were female. In addition, $51 \%$ of these individuals who showed interest in rugby were black, 28\% were white, 15\% were colored and 2\% were Indian (Repucom, 2012). Embarking on sponsorship deals within the South African rugby industry can therefore overcome language and cultural barriers as sponsors can then expose consumers from different cultural backgrounds to their brand or marketing messages.

As can be seen from the previously presented discussion, companies have valid reasons for embarking onto sponsorship endeavors. Like with all marketing communication tools, it is essential that sponsorship influences or changes consumer behavior in order to achieve organizational and marketing objectives. With that said, companies need to understand the very market segments they wish to reach. According to Tokuyama and Greenwell (2011), knowledge regarding the resemblances and variances among sport participants and spectators can be helpful for companies as this allows organizations to proliferate their customer base beyond their traditional consumers.

\section{Consumer behavior within the sports environment}

Consumer behavior is the behavior buyer's exhibit when seeking, gathering, purchasing, using and evaluating goods that the buyer expects will satisfy their needs and wants (Schwarz \& Hunter, 2008). In order for goods to thrive in the market, companies need to know their target audience, who they are, what they like, what motivates them to act in a particular manner and what they believe. Consumers are different and under different circumstances, they will approach decision-making in different ways. Kardes, Cline and Cronley (2011) describes the term 'consumer' to denote person or an organization that is compelled by their own unique needs and desires to purchase goods or services. A sports consumer on the other hand is regarded as a person or group who uses a sport or sportsrelated product or service in exchange for a direct payment (for example money to purchase a ticket to a sporting event) or indirect compensation such as buying a television on which sport is one form of entertainment) (Smith, 2008). Within the sporting environment, sports consumers can be classified into six segments as identified by Fullerton (2007):

Players: these are described as those persons who participate in that particular sport. The motivation behind this categorization of sports consumers is that individuals 
who play a particular sport will be more likely to enjoy watching sports in general. Although they are sports participants, they also become sports consumers by consuming the sport as a fan or a spectator. Players understand the capabilities needed by the sportsmen to perform at well and therefore become highly involved in the sport.

Patriots: these sports consumers consider sports or a particular sport as a platform to develop a sense of pride for their country. As a result, these sports consumers may be highly involved in a particular sport or with a team. Patriots value the performance of the team and appreciate the team's triumphant moments and may be dismayed by a loss. Patriots demonstrate their commitment to the team by attending the team's games and actively monitoring the team's performance on TV, the internet or on print media.

Appreciator: are individuals who admire the skills, hard work, solidarity and the achievement of the sportsmen. Appreciators are inspired to attend the sporting events by the thought of being able to witness the excellent skills of sportsmen as they may have a practical understanding of what goes into performing well on the field.

Socialites: these sports consumers consider sport is a platform of engaging with friends. Socialites attend the sporting even because they enjoy a pleasurable experience with specific individuals.

Friends: The motivation for attending sporting events may be to provide support for friends and family members who are participating in the sport. These individuals have a basic understanding of the sport but have no involvement beyond their effort to support their friends and family members

Voyeurs: these sports consumers consider sex appeal as an important factor. It is not the sport per se that attracts the voyeur or that the voyeur finds exciting, but rather the physical attractiveness of the participants

It is important that sponsors understand the type of sports consumers that will ultimately be exposed to their marketing messages. As can also be seen from the discussion above, sports consumers are motivated by varying factors to attend a sporting event and to a certain degree may impact their ability to pay attention to marketing messages. For example, if a sport consumer is motivated to attend a rugby match to support their friends or family member, their primary focus throughout the rugby match might just be concentrating on the performance of their loved one. They may end up not fully comprehending any marketing messages brought to their attention. The same can be said for those sports consumers who attend a ruby match for the social aspects. These individuals may hold conversations throughout the match and only focus on the game when tries care scored or when conversions are made. During breaks, these sports consumers may even wonder around the sporting vicinity to socialize and, in the process, miss the marketing messages. Therefore, organizations need to understand the motivation for attending the sporting event in order for marketers to intercept these sports consumers at various points during the sporting event.

\section{Conceptual framework for awareness}

According to Macdonald and Sharp (2003), brand awareness is considered to be the first building block in developing associations regarding a brand in the memory of the consumer. For a consumer to purchase a product, they need to be aware of the product offered by the brand. Brand awareness relates to the strength of the brand trace in the 
memory of the consumer which is reflected by the consumer's ability to effortlessly identify the brand under varying situations (Keller, 199). Brand awareness can be described as the strength of a brand's presence in the consumers' mind and to the extent and ease with which consumers recall the brand and can recognize the products and services with which the brand is associated (Boshoff \& Gerber, 2008). Aaker (1991) in Karam and Saydam (2015) describes the three levels of brand awareness as: brand acknowledgement: this is referred to as the ability of consumers to be familiar with a certain brand when asked to identify a perceived brand name from a group of brands within the same category; brand review: this refers to when the consumer is asked to name a brand within a specific group. Additionally, it is referred to as "unaided review" as consumers are not given any prior information from the item group; top of psyche: This is referred to as the first brand that the consumer can name among a given category.

Brand awareness is an important aspect in the consumer decision-making process because it is essential that customers remember the brand in the context of a given specific product category, awareness thus increases the likelihood that the brand will be among the brands considered by the consumer (Moisescu, n.d). Moisescu, (n.d) states that awareness also influences the judgments about brands in the consideration set, even without any brand associations in consumers' minds. In low involvement decision; where consumers do not need to search extensively for information in order to make a decision; minimal brand awareness levels may be enough to convince the consumer to make their final choice.

According to Koniewski (2012), brand awareness can be used as a strategy by consumers in order to save time when making purchase decisions. Brand awareness may therefore be inferred as a mental simplification specifically for cheap and easily disposable products such as food and every day-use products. Consumers tend to rely on brand awareness for certain instances however may also rely on the physical attributes of the product such as quality, functionality, taste or fragrance when making purchase decisions (Koniewski, 2012). Brand awareness is considered to have a more resilient influence on the successive purchases, if the product once tried out fulfilled the consumer's expectations then the consumer would most likely recall the specific brand the next time the consumer needs to make a purchase.

In essence, brand recall has the following effects desired by organizations (Koniewski, 2012): the recall of brands blocks off the other brands from the variety of substitutes in which the consumer makes his/her selection from; if consumers are familiar with a number of brands, consumers tend to select the brands they know well especially in the case where the consumer does not see any main differences between the competitors; good brand recall forms the basis for a clear and attractive brand image; brand recall together with high customer satisfaction levels converts into customer loyalty.

As can be seen from the above discussion, brand awareness can have a positive impact on how consumers to react. Organizations need to not only sell their products but also improve their brand awareness through various marketing communications tool. Jalleh, Donovan, Giles-Corti and Holman (2002) has demonstrated that awareness can be regarded as an output mechanism of measuring the effectiveness of sponsorship however; very little research has been conducted regarding the application of literature in the South African rugby industry. 
The purpose of this study was to explore which sponsors of the South African National Rugby team are sports consumers aware of as a result of the sponsorship. The secondary objectives of the study are as follows: to uncover the type of sports consumers that watch Springbok rugby matches; to reveal the factors contributing to the awareness of the Springbok sponsors

\section{Methodology}

The purpose of this study was to explore which sponsors of the South African National Rugby team are sports consumers aware of as a result of the sponsorship. A qualitative approach was considered to be appropriate as it allowed the researcher to understand how sports consumers interpret their experiences with sports consumption, how they conceptualize their views regarding sponsorship and what meaning they give to their experiences (Merriam, 2009). For example, rather than finding out how many sponsors sports consumers are aware of; which could be done through quantitative research; qualitative research allows the researcher to further understand which type of sponsors are sports consumers most aware of and why. A phenomenological research design was applied in this study as this research design assists the researcher in describing what all participants have in common as they experience a phenomenon; the sponsorship of the Springboks (Creswell, Hanson, Plano Clark \& Morales, 2007). This study focused on the precise declarations and experiences of the participants to allow the researcher to understand the effectiveness of sponsorship within the South African context (Creswell et al., 2007).

In this study, an inclusion criterion was used to devise the scope of the study and details regarding the target population (Nayar \& Stanley, 2015). The inclusion criteria used to identify the initial sample was as follows: males and females who were 18 years or older; any individual who had previously been exposed to a Springbok rugby match; any individuals who resided in the Tshwane area within Gauteng; any persons, who were able to understand, read, write and speak English.

As can be seen in the inclusion criteria, the target population for this study included consumers who had previously been exposed to a Springbok rugby match. To better describe the target population, the term 'exposed' in the context of this study is demarcated as following: persons that have watched a Springbok match at any rugby stadium or on a television set; persons that has seen branding on the Springbok playing apparel; persons that have seen sponsor messages on a television set or at any rugby stadium; persons that have attended a Springbok match as a social activity and, in the process, were exposed to sponsor messages and branding.

Based on the availability of participants on the day the researcher conducted the focus groups, the target population for this study consisted of females and male sports consumers who ranged between the ages of 18 to 25 years and 26 to 35 years. Participants were from various racial groups including African, Caucasian, Indian, Colored and Asian. Data for this study was collected by means of two focus groups; consisting of six individuals in each focus group; and naïve sketches. Naïve sketches are considered to be a self-report data collection instrument whereby participants describe their experiences and opinions in a written narrative (Chokwe \& Wright, 2012). According to Chokwe and Wright (2012), 
researchers embarking on qualitative studies can make use of narratives in place of, or in addition to, an interview. All participants were then given 15 minutes to complete the naïve sketches before the focus groups commenced. Naive sketches were deemed necessary for the data collection process as they provided participants with the opportunity to describe their views and opinions in writing regarding their awareness of the sponsors of the Springboks in an informal manner and in their own voice. Items to encourage visual stimulation were included in the naïve sketches and were a preferred tool to accurately explore which sponsors sports consumers were aware of.

The naïve sketches focused on achieving the secondary and primary objectives of this study. In determining the type of sports consumers that watch Springbok matches, the participants were provided given definitions of the types of sports consumers that exist. From the participants' understanding of the definition, they were required to categories themselves and explain why they believed they conformed to the given definition. The primary objective of the study was achieved by presenting participants with visual aids to determine which sponsors of the Springbok participants were aware of. The researcher presented participants with logos of various organizations and these logos were clustered into Group A, B and C. The participants were then asked to circle which of the given logos they believed were sponsors of the Springboks. Within each group, logos of Springbok sponsors and non-Springbok sponsors were included. With the aim of achieving the second secondary objective of this study, the participants were asked to describe the contributing factors to their awareness of the Springbok sponsors; in essence, what caused them to be aware of the sponsors. Once all naïve sketches were completed, they were submitted to the researcher who then commenced with the focus group. The questions that were asked in the naïve sketches were then discussed with the participants in the focus groups. Each focus group lasted 30 minutes and was conducted in a private office at the University of South Africa. The focus groups were also recorded to ensure data quality. The researcher concluded that data saturation was reached after two focus groups as no new information was observed.

Klenke (2008) states that quality assurance of data in qualitative research can be described through strategies such as credibility, transferability, dependability and confirmability. These concepts are considered to encompass the authenticity of the results obtained from the research. Credibility in this study was attained by prolonging the engagement with the participants and also building trust. This was done by honouring the views and opinions of the participants, ensuring that the participants are in an environment that encourages openness and honesty. In this study, the inclusion criterion that was used in selecting the target population was clearly described. This is done to ensure that future researchers who may wish to replicate the study can have sufficient information regarding the characteristics that the population should possess. Dependability was ensured by the recoding procedure. An independent coder was used to code the findings during the data analysis process. Confirmability was sanctioned by the participation of the independent coder in the data analysis process (Jooste, Khumalo \& Maritz, 2013). Since two focus groups were used to collect primary data from the participants, the data was supported by naïve sketches completed by the participants as well as recorded on an audio recorder (Jooste et al., 2013). 
Data collected was analyzed using content analysis. Content analysis is defined as the understanding of textual data by means of a systematic ordering process of coding and detecting themes or patterns (Zhang and Wildemuth, n.d). This qualitative data analysis method was used as it reduces the data, streamlines it by summarizing and constructing the data according to rules derived from existing theory (Malhotra, Birks \& Wills, 2012). The steps in the content analysis process highlighted by Zhang and Wildemuth (n.d.) were undertaken in the analysis process.

\section{Results}

The results of the study will now be discussed in this section. Table 2 provides a summary of the themes and categories identified in the analyses process as well as the objectives that the themes address in the study.

Table 2. Summary of themes and categories identified in the study

\begin{tabular}{|c|c|c|}
\hline Themes & Categories & Objectives \\
\hline $\begin{array}{l}\text { Theme 1: Types of } \\
\text { sports consumers }\end{array}$ & $\begin{array}{ll}\text { 1. } & \text { Socialites } \\
\text { 2. } & \text { Appreciators } \\
\text { 3. } & \text { Patriots } \\
\text { 4. } & \text { Friends }\end{array}$ & $\begin{array}{l}\text { Secondary objective } 1: \text { to investigate } \\
\text { the type of sports consumers that watch } \\
\text { springbok rugby matches }\end{array}$ \\
\hline $\begin{array}{l}\text { Theme 2: Awareness } \\
\text { of springboks } \\
\text { sponsors }\end{array}$ & $\begin{array}{ll}\text { 1. } & \text { Sponsors from Group A } \\
\text { 2. } & \text { Sponsors from Group B } \\
\text { 3. } & \text { Sponsors from Group C }\end{array}$ & $\begin{array}{l}\text { Primary objective: To explore how } \\
\text { aware sports consumers in Tshwane } \\
\text { are of the sponsors of the South African } \\
\text { National Rugby team, commonly known } \\
\text { as the Springboks }\end{array}$ \\
\hline $\begin{array}{l}\text { Theme 3: } \\
\text { Contributing factors } \\
\text { to the awareness of } \\
\text { the springbok } \\
\text { sponsors }\end{array}$ & $\begin{array}{ll}\text { 1. } & \text { Branding } \\
\text { 2. } & \text { Television } \\
\text { 3. } & \text { Other promotional tools }\end{array}$ & $\begin{array}{l}\text { Secondary objective 2: To determine } \\
\text { the factors contributing to the } \\
\text { awareness of the Springbok sponsors }\end{array}$ \\
\hline
\end{tabular}

Source: Derived from the results.

\section{Theme 1: Types of sports consumers}

Sports consumers may attend a sporting event for various reasons and these reasons may assist in determining the various types of sports consumers. Hunt, Bristol and Bashow (1999) identified a conceptual approach to classifying sports fans. These classifications are true in this study as sports consumers felt that they conformed to the classifications given by Hunt, Bristol and Bashow (1999). The first category that the participants conformed to was that of socialites. This represents individuals who enjoyed the social component relating to watching a rugby game. The participants indicated that watching rugby was a platform for them to socialize with their loved ones. The participants made comments such as "... I watch with friends at social gatherings ..." and "this is usually a time where as friends we get together on the purpose of catching up and also enjoying the sport" which validate that some sports consumers may consume sports purely for the social aspect. The following comments from the participants validate the findings: 
- "... do not know how to play but my primary motivation is to join my friends and get to spend time with them ..."

- "... usually a time where as friends we get together with the purpose of catching up ..."

- "... watching the game with friends and family makes it more interesting as we have bets between each other ..."

- "... watch it with friends either at a bar or at someone's house for a braai ..."

Some participants considered themselves to be more appreciators rather than socialites. Appreciators are sports consumers who admire and appreciate the skill required to participate in the sport as well as the dedication and achievements of the players (Fullerton, 2007:286). A participant noted that "... sportsmen and women work really hard to be their best and to represent the country ..." Participants also indicated that the quality of the rugby event influenced their decision to watch the sport; "... quality of the event influences the need to watch it ..." For example, the Rugby World Cup is considered to be a prestigious and high-quality event as it is world-renowned, therefore some individuals were inclined to watch the particular event as the participants view it as "good games". This is validated by the comment make by participants; "... enjoy watching good games ..."

The third type of sports consumer that was identified from the participants, were patriots. The participants in this study displayed an understanding of what this category meant; "... I understand the nation building aspect." Participants considered themselves to be patriots because they felt a sense of national pride when the Springboks play. Participants noted that they "... get a sense of pride when I see our sportsmen play against other countries ..." and that "... it makes me proud of my country ..." A participant mentioned that they felt that rugby as a sport and the Springboks "... brings people together ..."

The last type of sports consumer identified is referred to as friends. Friends are individuals who felt that "... motivation is to provide friends and family members who participate ..." A female participant in the study particularly mentioned that their "... husband plays soccer and therefore support him ... applies to any sport ..."

Exploring the types of sports consumers was necessary in this study as literature has found that consumers' sport involvement positively influenced sponsor awareness, corporate image and consumer purchase intentions (Ko, Kim, Claussen \& Kim, 2008). If consumers are motivated by various aspects to consume rugby or have varying levels of involvement, surely this may impact their ability to pay attention to marketing messages during rugby games. For example, suppose participants have low involvement levels or are motivated by social aspects to attend a Springbok rugby march, the participants would probably rather have a conversation with their friends during the match interval and might not pay attention to any sponsor messages communication.

Now that the types of sports consumers have been identified, the discussion will now provide insight on which sponsors of the Springboks sports consumers were aware of. In the naïve sketches, sports consumers were given visual material; logos of organizations who were sponsors and non-sponsors of the Springboks. These organizations were clustered into three groups whereby participants had to identify these organizations they believed where sponsors of the Springboks. The correct combination of the Springbok sponsors that the participants could have identified is provided in Table 3. It is important to note that Absa and BMW were title sponsors of the Springboks at the time in which data 
collection. According to Sport24 (2015a), Absa decided not renew their sponsorship contract with the Springboks as of 2016. BMW's five-year sponsorship deal came to an end in December 2015 and the organization also decided to not renew their contractual obligation with the Springboks (Sport24, 2015). The findings below represent the second theme that was identified during the data analysis process.

Table 3. Correct combination of Springbok sponsors

\begin{tabular}{|c|c|}
\hline Group & Correct Springbok Sponsor \\
\hline A & $\begin{array}{ll}\text { - } & \text { Absa } \\
\text { - } & \text { Asics } \\
\text { - } & \text { BMW }\end{array}$ \\
\hline B & $\begin{array}{ll}\text { - } & \text { Castle } \\
\text { - } & \text { Vodacom } \\
\text { - } & \text { Shield }\end{array}$ \\
\hline $\mathrm{C}$ & $\begin{array}{ll}\text { - } & \text { Klipdrift } \\
\text { - } & \text { Gilbert } \\
\text { - } & \text { Virgin Active }\end{array}$ \\
\hline
\end{tabular}

Source: Derived from the results.

\section{Theme 2: Awareness of Springbok sponsors}

As can be seen from Table 2, the second theme identified is awareness of the sponsors of the Springboks. This question addresses the primary objective of this study. In category one, the participants correctly identified Absa as a sponsor of the Springboks. A participant commented that they "... circled ABSA because it is the one that really comes to mind when you think of rugby. I am not familiar with all the sponsors but when I thought of ABSA I remembered rugby ..." During the focus groups, the participants were in agreement that Absa was definitely a sponsor as "ABSA has got those big signs on the front of their shirts." Generally, the participants may have not been certain about the other companies cluttered in Group A however, Absa seemed to stick out in the minds of the consumers; "... a lot of organizations, they are like known for sponsorships... I think ABSA ..." Although not all the participants knew that BMW was a Springbok sponsor, some indicated that they saw BMW signs at the stadium during a Springbok game.

Participants justified their awareness by saying that "... BMW signs are usually everywhere in the stadiums, I have seen them before." Another participant concurred with the group that BMW was a sponsor within category one; "... I mean it is their kit, so it is not something that you can miss really and then I think the only other one is BMW, that is because I am a fan so that's the association." Lastly, the findings suggest that Asics was not dominantly known as a sponsor of the Springboks. One of the participants commented that; "... I am not familiar with all the sponsors but when I thought of ABSA I remembered rugby and also I think it is ASICS ... I know they produce a lot of sporting gear so they are the two that make sense." Category two provides Sponsors clustered in Group B. These sponsors were not title sponsors of the Springboks therefore their branding did not appear on the playing kit of the Springboks.

The findings revealed that the participants correctly mentioned the sponsor they associated with the Springboks, namely Castle. "... usually when it is rugby, it is a celebration 
so everybody is happy and enjoying themselves and drinking beer." This demonstrates the participants' interpretation that the Castle culture was more evident in the sponsorship. They associated the celebration that takes place during rugby games and the Castle products consumed during this time. Another participant made commented on the Castle sponsorship association relating to race: "... Castle in my opinion, is primarily, Castle and Black Label, those are things that are primarily enjoyed by Afrikaans speaking people who are largely patrons of rugby, if I am being a stereotypical person, so it makes sense that rugby would have Castle as their main sponsor and not Heineken or Castle Light which is enjoyed by people who don't necessarily watch that much rugby" The findings also reveal that Vodacom was recognized by some of the participants as a sponsor of the Springboks.

The general dynamic within the groups was one of uncertainty; "I circled Vodacom because I wasn't sure; I know it has got something to do with rugby." Generally, the group was apprehensive about naming Vodacom as a sponsor. "... that is also difficult, I remember that the brand has something to do with rugby but I can't remember, is it is the Currie Cup or the Springbok or Blue Bulls team ..." another participant remarked that "I assume if they sponsor the rugby, they will sponsor the main team as well." Within category 2, Shield was least recognized by participants as a sponsor. Participants were uncertain and concurred that "... even with Shield, I think I remember an ad, a supporting ad with Shield but I wasn't sure if it was a soccer one because I know who soccer sponsors are, and also rugby I am not sure if they are also sponsored but I know some of them are sponsored."

Category three provides a cluster of sponsors who are official sponsors to the Springboks. The findings suggest that the participants were highly aware that Gilbert was a sponsor of the Springboks. From the focus groups, it was clear that the participants were drawing these conclusions from what they perceived to be the value that the company added to the Springbok brand. The participants indicated that Gilbert possibly supplied rugby balls and could therefore be sponsors of the Springboks. In the focus groups, participants unanimously agreed that Virgin Active was a sponsor. Within the groups, participants were not really forthcoming about why they thought Virgin Active was a sponsor. Lastly, the findings reveal that the participants were not very aware of the sponsorship agreement between the Springboks and Klipdrift. Minimal comments were made regarding Klipdrift as a sponsor. One participant commented that they "... remember Klipdrift, you know where they spray on the grass" and another concurred; "I remember Klipdrift on the grass."

Qualitative research techniques were deemed suitable for this study as they enabled the researcher to seek underlying insights into consumer behavior. It is for this reason that the participants were probed in the focus groups regarding why they were aware of the sponsors of the Springboks.

\section{Theme 3: Contributing factors to the awareness of the springbok sponsors}

As can be seen from Table 2, factors that contributed to the awareness of the Springbok sponsors were branding aspects, television as well as other promotional tools (category 1, 2 and 3 respectively). The findings reveal that the first contributing factor to the sponsorship awareness is branding. The participants mentioned that "... even on the clothing, on the gear, there is always a huge logo which I am assuming that the biggest logo there is the main sponsor and then there will be other smaller ones here and there ..." Other participants within 
the group agreed that sponsors "... brand the stadiums around the field ..." "... they painted it in the middle, you can't really miss it"

Television was identified by the participants as the second factor that contributed to their awareness of the Springbok sponsors. The participants mentioned that they had previously seen TV adverts that would communicate the association with the Springboks. In cases where participants watched a Springbok match on TV, they paid attention to the popup adverts from the sponsors during the allocated interval during the match (informally referred to as half time). Participants were particularly fond of these pop-up ads and thought they were not disruptive to their television viewing. One of the participants further elaborated that "...television ads that focus on the team that's being advertised. You find that they do mention the company that is sponsoring or sometimes you have an ad of the company and at the end they will say, official sponsor of the Springboks or something like that. So it does draw attention."

Other promotional tools were mentioned by participants as a contributing factor to their awareness of the Springbok sponsors. Participants indicated that to a lesser extent the marketing of free goods and competitions run by sponsors which included the Springbok brand created awareness. "Even with competitions, because a lot of the companies, or sponsors they run competitions for the team." Print advertising was among the promotional tools mentioned by the participants; "... the banners and posters and everything so they are doing their marketing through branding." A few participants also agreed that "... social media..." had some influence on the extent to which participants were aware of the sponsor, although not used often.

\section{Discussion}

Theme 1 addresses the first secondary objective of this study which was to uncover the types of sports consumers that watch Springbok matches. The findings indicate that socialites were the most dominant type of sports consumer within the study. Participants watched rugby because it was an opportunity to socialize with friends and family. It can be deduced that for these types of sports consumers, the environment or context in which the sport is consumed plays a bigger role in the consumption of the sport than the sport itself. The findings also revealed that some sports consumers are appreciators; they enjoyed watching Springbok games due to the skill displayed by the players. In addition, what appreciators perceived as 'high quality' rugby events motivated them to watch the Springboks. Examples of highly regarded rugby events are World Cup matches as they include the very best teams in the world competing for the prestigious title of being world champions. The findings revealed that participants were also patriotic and displayed great pride in the victorious performance of the Springboks. They felt proud that they were South African when the Springboks play and understood that victorious moments brought the country together, assisting to build the nation through sport. The last category illustrating the types of sports consumers found in this study was that of friends. These participants watched rugby because they supported their friends or family members who participated in the sport. The participants did not necessarily like the sport, but provided support for their loved ones.

Theme 2 addresses the primary objective; which was to explore which sponsors of the South African National Rugby team are sports consumers aware of as a result of the 
sponsorship. The findings suggest that the participants were more aware of the key sponsors; these were sponsors who had their branding on the Springboks' playing jersey. Absa was a sponsor of the Springboks from 2011 to 2015 (Mufumba Consulting, 2009; Sport24, 2015) and the study found that participants were aware that Absa was a sponsor of the Springboks. The participants further stated that Absa came to mind when they thought of rugby. When data for the study was collected, BMW was also a sponsor of the Springboks. BMW's contractual obligation with the Springboks has since expired. The study found that the participants were aware of the sponsorship agreement that was in place. They mentioned that they had previously seen BMW branding in and around the sporting arena where the Springboks had played as well as on the Springboks' playing kit. These findings are supported by Wakefield (2012), who states that title or primary sponsors of well-known entities such as the Springboks often already enjoy strong brand recognition. In his study, Wakefield (2012) suggest that sports spectators are aware of title sponsors of an event, however are less engaged with other stimulation aspects, such as collaborating activities at the sponsored event. Since Asics is one of the main sponsors of the Springboks, its corporate logo is visible on the Springboks' playing jersey. Although some participants were aware of the sponsorship, their awareness and association was not significantly strong. Asics had been a sponsor of the Springboks from 1 January 2014 and will be until 31 December 2019. The reason for the insignificant awareness of the Asics sponsorship of the Springboks could be that the organization was a relatively new addition to the Springboks' body of sponsors. It is important to note that new sponsorship alliances are continually being formed with sporting organizations. In some cases, very little media communication is done which then leave the consumers in the dark regarding new sponsorship deals in place. McAlister, Kelly, Humphreys and Cornwell (2012) found that long-standing sponsors continue to benefit from consumers associating their brand with the sponsored event, even after the sponsorship arrangement has formally ended. However, this still threatens the effectiveness of the sponsorship for the new sponsor as consumers may still recall the former sponsor. This therefore supports the importance of sufficient and effective communication needed regarding new sponsorships as it impacts on awareness. Other sponsors that may not participially have their branding on the Springbok playing jersey was inclusive of Castle, Vodacom, Shield, Virgin active, Gilbert and Klipdrift. The findings suggest that the participants of this study were aware of Castle, Vodacom and Shield as sponsors however, to a lesser degree Shield was least recognized. The participants identified a strong association between the Springboks and Gilbert, as the company is a supplier of rugby balls. Virgin Active and Klipdrift were identified as sponsors; however, participants were generally not well aware of this sponsorship association.

Pitts and Slattery (2004) found that time has a positive effect on sponsorship awareness levels, meaning that awareness of sponsors can improve with time. Walraven, Bijmolt and Koning (2014) provide an empirical argument for building long-term relationships. They highlight that sponsorship awareness levels increase over time, and the highest increase of awareness may occur in the second year of sponsorship. This supports the findings as sponsors such Absa and BMW had been sponsors of the Springboks for more than four years respectively. Castle particularly has been associated with the Springboks for more than two centuries. In April 2016, SAB announced that they would renew their SA Rugby sponsorship until 2020 (SARU, 2016). This meant that the world-renowned Castle 
Lager brand would extend its association with the SA rugby to 23 years (SARU, 2016). This supports the findings of this study that suggest that longevity contributes significantly to awareness. The findings of this study contribute to the body of knowledge regarding the effectiveness of sponsorship within the sports environment. Brand awareness is an important aspect in the consumer decision-making process because it is essential that customers remember the brand in the context of a given specific product category, awareness thus increases the likelihood that the brand will be among the brands considered by the consumer (Moisescu, n.d). Moisescu, (n.d) states that awareness also influences the judgments about brands in the consideration set, even without any brand associations in consumers' minds. Herrmann, Corneille, Derbaix, Kacha and Walliser (2013) found that sponsorship influences the probability that an established brand becomes part of the consideration set, even when there isn't clear awareness of the sponsorship. In the context of their study, Herrmann, Corneille, Derbaix, Kacha and Walliser (2013) defined a consideration set as "a subset of brands that the consumer regards as acceptable and will consider when contemplating a purchase in the category." From their findings as well as the findings of this study, it is clear that sponsorship can be regarded as an effective tool to create brand awareness. Awareness is therefore essential when trying to establish a brand as a good alternative in the decision-making process.

Theme 3 addresses the second secondary objective of this study which was to reveal the factors contributing to the awareness of the Springbok sponsors. This study suggests that participants were aware of the sponsors primarily due to the branding on the Springbok playing jerseys, branding in and around the sporting arenas as well as television adverts. The findings reveal that awareness was also due to other promotional tools such as social media and competitions. Millan and Ball (2012) mentioned that one of the most beneficial aspects of social media to sponsors are its interactive capabilities, permitting for two-way communication with consumers and providing opportunities to build a profound relationship. A downside to using social media however, it that brands could lose control of how much content is disclosed to consumers (Millan \& Ball, 2012). Sponsors therefore need to set distinctive objectives and to leverage social media within their marketing strategy. This supports the findings of this study, that leveraging is imperative in ensuring that sponsorship is effective. Future research can focus on examining the most effective leveraging tools within sporting environment. This could assist managers in choosing the correct marketing tools that will achieve key organizational objectives; which may be to improve sales. Authors such as DeGaris and West (2013) conclude that it is not unrealistic for companies to link sponsorship programs directly to product sales.

\section{Recommendations}

Consumers in this study were predominantly aware of the main sponsors of the Springboks; for example, Absa and BMW. Companies such as Klipdrift and Shield who sponsors at the time in which the data was collected; were not well associated with the Springbok brand in the minds of the participants. New sponsorship deals are continually being made and consumers may not be well informed about new additions to the Springboks sponsorship family. Therefore, it is recommended that sponsors who may not be title sponsors of the Springboks engage with consumers (for example, executing brand activation strategies) more as this will help the consumers link the brands to the Springboks and improve awareness of the sponsors.

Vol. 12, No. 1, Spring, pp. 103-123, ISSN 1842-0206 | Management \& Marketing. Challenges for the Knowledge Society 
Longevity of the sponsorship agreement between the Springboks and the sponsors could play a vital role in the awareness levels of consumers. Companies such as Castle and Vodacom, which have been sponsoring the Springboks for many years, were associated with the Springboks in the minds of the participants. However, what about those sponsors who only opt to sponsor the Springbok brand for a 'limited' period of time? Such sponsors unfortunately simply cannot rely on longevity to increase awareness of their brand through the sponsorship partnership. Some sponsorship contractual obligations may only be for two or three years, and so sponsors need to carefully map out what leveraging tools will be used regularly to improve awareness. A two or three-year sponsorship deal can achieve a number of marketing objectives if utilised correctly. It is recommended that sponsors carefully iron out what the aim of the sponsorship agreement is; the sponsorship of the Springboks may be quite costly therefore sponsors need to make sure that they reap the maximum results. Additionally, it is recommended that sponsors with short term sponsorship deals establish measures that will evaluate the effectiveness of the sponsorship. If the awareness of their brand hasn't increased significantly from the sponsorship; sponsors should develop initiatives to remedy the situation.

Awareness is an important aspect that sponsors should not take for granted. Consumers who are aware of a brand and what the brand offers may translate in to consumers considering the brand during the decision-making process; therefore, it is recommended that sponsors ensure that their sponsorship of the Springboks helps improve the awareness of their brand in the minds of the consumers.

\section{Conclusion}

This study contributes to sponsorship literature relating to the effectiveness of sponsorship; particularly from a South African perspective. The study found that sponsorship created awareness of sponsors among sports consumers. This would imply that sponsorship can have an impact on the sponsors brand equity. The study highlights the impact that the sponsorship of the South African national rugby team (The Springboks) has had on the brand awareness element of brand equity for the Springboks sponsors. Awareness levels should not be taken for granted by sponsors as awareness of the brand may impact what alternatives consumers consider during the decision-making process. Springbok sponsors continuously change; for various reasons, this highlights the idea that sponsorship isn't an easy tool and if unmanaged, success is not inevitable. This study shows that just because a company is a sponsor of the Springbok brand, that consumers will be well aware of the sponsorship. Sponsors need to initiative powerful leveraging tools to ensure that their sponsorship is effective. Careful planning and execution is therefore needed when embarking on sponsorship within the South African market.

The study further contributes to the field of sports marketing in South Africa. From the findings of the study, sponsors are encouraged to ensure that the message that they wish to portray through the sponsorship is unique to the audience they wish to appeal to. Rugby in South Africa particularly appeals to a vast dynamic group of consumers, as identified in the research conducted by Repucom (2012). The study contributes to the body of knowledge in South Africaby highlighting that consumers are motivated by various factors to consume rugby and therefore companies need to clearly identify who they are 
targeting (i.e. socialites, appreciators, patriots and friends) (Hunt et al., 1999). Once this is done, messages can be developed uniquely for the specific target audience identified. For example, if someone is attending a rugby match because they enjoy the social aspect of rugby, they will be more focused on enjoying their surroundings and may not necessarily pay attention to the rugby match or to any messages that the sponsor may convey during a rugby match. This will result in the message failing to capture the target market's attention and convincing them to purchase. In conclusion, sponsorship can be a very expensive tool to use and therefore companies need to correctly identify who they wish to reach with the sponsorship in order for the sponsorship to yield the desired return on investment.

\section{References}

Alay, S. (2008), "Female consumers' evaluations of the sponsorship and their response to sponsorship", South African Journal for Research in Sport, Vol. 30, No. 2, pp. 15-29.

Amoako, G.K., Dartey-Baah, K., Dzogbenuku, R.K. and Kwesie, S. Jnr. (2012), "The effects of sponsorship on marketing communication performance: A case study of Airtel Ghana", African Journal of Marketing Management, Vol. 4, No. 2, pp. 65-79.

Boshoff, C. and Gerber, C. (2008), "Sponsorship recall and recognition: The case of the 2007 Cricket World Cup", South African Journal of Business Management, Vol. 39, No. 2, pp. 1-8.

Chokwe, M.E. and Wright, S.C.D. (2012), "Caring as a core concept in educating midwifery learners: A qualitative study", Health SA Gesondheid, Vol. 17, No. 1, pp. 1-7.

Cornwell, T.B., Roy, D.P. and Steinard, E.A. (2001), "Exploring managers' perceptions of the impact of sponsorship on brand equity”, Journal of Advertising, Vol. 30, No. 2, pp. 4151.

Creswell, J.W., Hanson, W.E, Plano Clark, V.L and Morales, A. (2007), "Qualitative research designs: Selection and implementation”, The Counselling Psychologist, Vol. 35, No. 2, pp. $236-264$.

DeGaris, L. and West, C. (2013), "The effects of sponsorship activation on the sales of a major soft drink brand", Journal of Brand Strategy, Vol. 1, No. 4, pp. 403-412.

Fullerton, S. (2007), Sports marketing. New York: McGraw-Hill Irwin.

Gerber-Nel, C. (2004), "Determination of the brand equity of the provincial, regional and national rugby teams of South Africa", Doctoral dissertation. South Africa: UNISA.

Karam, A.A. and Saydam, S. (2015), "An analysis study of improving brand awareness and its impact on consumer behavior via media in North Cyprus (A case study of fast food restaurants)", International Journal of Business and Social Science, Vol. 6, No. 1, pp. $66-80$.

Herrmann, J., Corneille, O., Derbaix, C., Kacha, M. and Walliser, B. (2013), "Implicit sponsorship effects for a prominent brand", European Journal of Marketing, Vol. 48, No. 3/4, pp. 785-804.

Jalleh, G., Donovan, R.J., Giles-Corti, B. and Holman, D.J. (2002), "Sponsorship: Impact on brand awareness and brand attitudes", Social Marketing Quarterly, Vol. 8, No. 1, pp. $35-45$.

Kardes, F.R., Cline, T.W. and Cronley, M.L. (2011), Consumer behavior: Science and practice, South-Western: Cengage Learning. 
Keller, K.L. (1993), "Conceptualizing, measuring and managing customer-based equity", Journal of Marketing, Vol. 57, No. 1, pp. 1 - 22.

Klenke, K. (2008), Qualitative research in the study of leadership, Bingley: Emerald Group.

Ko, Y.J., Kim, K., Claussen, C.L and Kim, T.H. (2008), "The effects of sport involvement, sponsor awareness and corporate image on intention to purchase sponsors' products", International Journal of Sports Marketing and Sponsorship, Vol. 9, No. 2, pp. $6-21$.

Koenderman, T.F. (2011), "Losers at rugby, winners in advertising", available at: web.ebscohost.com/ehost/detail?vid=4\&hid=12\&sid=2dc10641-b10d-48da-bcfd372fb17fde4f\%40sessionmgr4\&bdata=JnNpdGU9ZWhvc3QtbGl2ZSZzY29wZT1zaXR $\mathrm{l} \# \mathrm{db}=\mathrm{bth} \& \mathrm{AN}=71092866$ (accessed January 19, 2016).

Koniewski, M. (2012), "Brand awareness and customer loyalty", available at: www.research-pmr.com/userfiles/file/wp/Brand-Awareness-and-CustomerLoyalty.pdf (accessed January 19, 2016).

Levet, S. (2012) "Business and rugby", Finweek Magazine, pp. 9-11

Macdonald, E. and Sharp, B. (2003), "Management perception of the importance of brand awareness as an indication of advertising effectiveness", Marketing Bulletin, Vol. 14, No.2, pp. 1 -11.

Macdonald, E.K. and Sharp, B.M. (2000), "Brand awareness effects on consumer decision making for a common, repeat purchase product: A replication", Journal of Business Research, Vol. 48, pp. 5-15.

Mail \& Guardian (2012), "Rugby fans lose out on SABC's new test pattern", available at: mg.co.za/article/2012-06-14-no-rugby-test-match-for-sabc (accessed January 19, 2016).

Malhotra, N.K., Birks, D.F. and Wills, P. (2012), Marketing research: An applied approach, 4th ed., Prentice Hall, Harlow.

Marshall, D.W. and Cook, G. (1991), "The corporate (sports) sponsor”, International Journal of Advertising, Vol. 25, No. 11, pp. 307-324.

McAlister, A.R., Kelly, S.J., Humphreys, M.S. and Cornwell, T.B. (2012), "Change in a sponsorship alliance and the communication implications of spontaneous recovery", Journal of Advertising, Vol. 41, No. 1, pp. 5-16.

Meenaghan, T. (2001), "Understanding sponsorship effects", Psychology \& Marketing, Vol. 18, No. 2, pp. 95-122.

Merriam, S. B. (2009), Qualitative research: A guide to design and implementation. San Francisco, Wiley \& Sons.

Millan, A. and Ball, M. (2012), "The use of social media as a tool for consumer brands to leverage sponsorship of sporting events: a qualitative analysis", International Journal of Sales, Retailing and Marketing, Vol. 13, pp. 27 - 39.

Moisescu, O.I. (n.d.), "The importance of brand awareness in consumers' buying decision and perceived risk assessment", available at: www.mnmk.ro/documents/2009/ 10_Moisescu_FFF.pdf (accessed January 19, 2016).

Mufumba Consulting (2009), "The business of rugby in South Africa", available at: mufumba.com/?p=51 (accessed January 19, 2016).

Nayar, S. \& Stanley, M. (2015), Qualitative research methodologies for occupational science and therapy. Oxon: Routledge. 
Pitts, B.G \& Slattery, J. (2004), "An examination of the effects of time on sponsorship awareness levels", Sport Marketing Quarterly, Vol. 13, pp. 43 - 54.

Repucom (2012), "Consumer and television audience analysis rugby”, August 8, 2012.

Rugby Football History (2007), "The history of South African rugby", available at: www.rugbyfootballhistory.com/south_africa.html (accessed January 19, 2016).

SARU (2016), "SAB renews SA Rugby sponsorships until 2020", available at: www.sarugby.net/news/sab-renews-sa-rugby-sponsorships-until-2020/ (accessed January 19, 2016).

SARU (2011), "History of the game", available at: www.sarugby.co.za/content.aspx? contentid=7535\&statscatid=2\&statsteam=South\%20Africa (accessed January 19, 2016).

Schwarz, E.C. and Hunter, J.D. (2008), Advanced theory and practice in sport marketing, Elsevier, London.

Shanklin, W.L. and Kuzma, J.R. (1992), "Buying that sporting image", Marketing Management, Vol. 1, No. 2, pp. 59-67.

Shimp, T.A. (2010), Advertising, promotion and other aspects of integrated marketing communications, Cengage, South-Western.

Smith, A., Graetz, B. and Westerbeek, H. (2008), "Sports sponsorship, team support and purchase intentions", Journal of Marketing Communications, Vol. 14, No. 5, pp. 387404.

Sport24 (2015a), "Boks lose second sponsor in as many days, available at: www.sport24.co.za/Rugby/boks-lose-second-sponsor-in-as-many-days-20151123 (accessed January 19, 2016).

Sport24 (2015b), "SARU's open letter to the nation", available at: www.sport24.co.za/Rugby/WorldCup/Open-letter-from-SARU-to-SA-20150909 (accessed January 19, 2016).

Sport24 (2014), "SARU announces small profit", available at: www.sport24.co.za/Rugby/ SARU-announces-small-profit-20140328 (accessed January 19, 2016).

Sport Know How (2011), "South African Rugby Football Union", available at: www.sportsknowhow.com/rugby/rules/south-african-rugby-football-union.html (accessed January 19, 2016).

Springbok Supporter (2011), History of the Springbokke. available at: www.springboksupporter.co.za/SARU/History.aspx (accessed January 19, 2016).

SuperSport (2012), "SARU agrees ground-breaking deal with players", available at: www.supersport.com/rugby/springboks/news/120602/Saru_agrees_groundbreaki ng_deal_with_players (accessed January 19, 2016).

Tassiopoulos, D. (2010), Events management: A developmental and management approach, Juta, Kenwyn.

Telegraph Media (2008), "A short history of the Springboks", available at: www.telegraph.co.uk/news/3269349/A-short-history-of-the-Springboks.html (accessed January 19, 2016).

Wakefield, K.L. (2012), "How sponsorships work: The sponsorship engagement model", Event Management, Vol. 16, pp. 143 - 155. 
Walraven, M., Bijmolt, T, H, A and Koning, R. H. (2014), "Dynamic effects of sponsoring: How sponsorship awareness develops over time", Journal of Advertising, Vol. 43, No. 2, pp. 142-154.

Wilkins, V. (2012), "Understanding loyalty and motivation of professional sports fans", Unpublished thesis, University of Nevada.

Zhang, Y. and Wildemuth, B. M. (n.d), "Qualitative analysis of content", available at: www.ischool.utexas.edu/ yanz/Content_analysis.pdf (accessed January 19, 2016). 